\title{
Experimental Methodology of Optimum Coagulation Activity on River Water using Chemical and Natural Coagulants for Different PH Ranges
}

\author{
C. RAMANJANEYULU
}

\begin{abstract}
The present study is related to determination of optimum dosage of natural coagulant and chemical coagulant to bring down the turbidity of the considered river water by maintaining different $\mathrm{pH}$ ranges. The conversion of waste water into unpolluted water as became challenge now a days. In the present investigation, a focus is made on Turbidity characteristic of waste water and an attempt is made to treat water so as to utilize it by removing its turbidity. After removal of turbidity, the water should undergo again some stages of purification. Before undergoing further purification, water should be made turbid free. To make water a turbid free, two types of coagulants are considered in this present study which are natural coagulant and chemical coagulant. The coagulant is orange peel powder natural one and the other is Alum, a chemical coagulant. Three series of water samples were considered by varying $\mathrm{pH}$ values $(6,7$ and 8.5). Other qualities of water like Turbidity, alkalinity and acidity were also tested before and after the process of coagulation. In this study an optimum dosage of coagulant was determined. The samples of river were collected from nearby flowing Kundu River, Nandyal (M), Kurnool (Dist)-A.P. The test results show that the optimum dosage of orange peel powder was found at $103 \mathrm{mg} / \mathrm{l}$ with 0.3 NTU Turbidity with Turbidity removal efficiency of 98.68\%and by using Alum the optimum dosage was found at 26 $\mathrm{mg} / \mathrm{l}$ with $0.3 \mathrm{NTU}$ Turbidity with Turbidity removal efficiency of $98.68 \%$.
\end{abstract}

Index Terms: Orange Peel powder, Alum, Coagulation, Turbidity, Optimum dosage

\section{INTRODUCTION}

As industrialization and urbanization is growing in fast and exponential way, the necessity and requirement of water is going on increasing day by day. Reaching the water requirements for the present demand of water is becoming a great challenge in the present days as resources of fresh water is less and utilization of water is quite more. If there is no sufficient supply of water to meet the domestic needs of the society, lot of problems could be faced by the living eco system in the society, which lead to heavy disturbances in their routine daily life. So, one has to practice utmost care in utilizing water as there is severe scarcity. As water occurs in its natural state, it contains foreign bodies which are carried by it from the point of its birth to the end of flow. Once the water is utilized industrially or domestically, it again gets

Revised Manuscript Received on July 22, 2019

C.RAMANJANEYULU,

Civil Engineering,RGM College of Engineering \& Technology, Nandyal, India contaminated. Industrial waste water also sometimes contains hazardous substances mixed into it. Once, this polluted water is dumped or disposed into fresh water bodies, it contaminates entire ecosystem of aquatic life living in them.

This contaminated water is conveyed from one place to another place though out the length of the flow and if this water is utilized by the living societies beside these water bodies, they also get affected due to the adverse effects caused by the contamination. No matter up to how much extent, the water contaminated, before dumping or before disposal into such fresh water bodies, it must be made toxic free by some preliminary treatment. Sometimes there will be more scarcity of water in some areas, due to which the same water is to be utilized for to serve the purpose and being helpless, the contaminated or waste water is to be again treated to make it fit for that particular use. In this present study, Kundu River water is considered. It is a tributary of Penna River.

The water sample collected was from a town named Nandyal of Kurnool district, Andhra Pradesh, Nandyal is on the banks of Kundu River. In and around Nandyal there are many factories and industries established. We can find some industries on the banks of Kundu River also. Most of them dump wastes in Kundu River and for this reason; this river's water sample was considered for the study. Three series of water samples (by varying $\mathrm{pH}$ ) are tested initially to obtain their $\mathrm{pH}$, turbidity, acidity and alkalinity. To utilize this river water which is turbid due to foreign bodies, its initial turbidity is to be reduced in order to progress to further treatment. For the considered three series of water samples, coagulation is done to bring down the turbidity up to standards with the help of coagulants. In this work, sedimentation aided with coagulation is adopted.

\section{LITERATURE REVIEW}

Wafai EL-Hosseni Ahmed et al. [1] studied Effect of irrigation water $\mathrm{pH}$ on some soil properties and growth of some pear rootstocks grown on sand and calcareous soils. Here two different rootstocks of pear that is Pyrus Communis and Pyrus Betulaefolia were grown on sand and calcareous soils by supplying irrigation water having $\mathrm{pH}$ values $6.0,6.5$, 7.0, 7.5, 8.0. The results showed that for Pyrus Betulaefolia, pH 6 was best in sand soil and pH 7 in calcareous soils. For Pyrus Communis, pH 7 is best in sand soil and $\mathrm{pH}$ 6in calcareous soils. When the

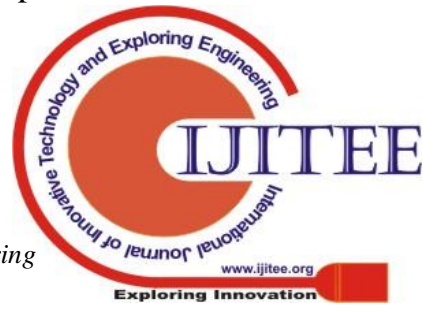


irrigation water having $\mathrm{pH}$ values 6 and 7 was supplied to plants, it showed more vegetative growth than that in other $\mathrm{pH}$ values [1]. Akbar Baghvand et al. [2] studied Optimizing coagulation process for low to high turbidity waters using aluminum and Iron salts. Synthetic turbid water using kaolin clay was prepared for initial turbidities of 10, 50, 100, 200, 500 and 1000 NTU. Alum and Ferric Chloride were added and tested for different $\mathrm{pH}$ values ranging between 4 to 8 . It was found that $92.9-99.4 \%$ of turbidity was reduced using Ferric Chloride and 82.9-99.0\% was reduced using Alum [2]. Bai ChuanCao et al. [3] studied Effects of $\mathrm{pH}$ on coagulation behavior and floc properties in yellow river water treatment using ferric based coagulants. In this study polyferric silicate sulphate and poly ferric sulphate were used in yellow water treatment.

The results gave that excellent organism removal efficiency was their when $\mathrm{pH}$ was 5.5. Joseph Marie ${ }^{4}$ studied Effect of water treatment residuals (Aluminum and Iron Ions) on human health and drinking water distribution systems. They studied that use of aluminum treated water leads to Parkison dementia, Amyotrophic lateral sclerosis, Alzheimer's disease. The residual concentrations of aluminum greater than $0.4 \mathrm{mg} / \mathrm{l}$ in treated water leads to formation of gelatinous substance in distribution network that reduces the low and alters the water quality [6].

The presence of residual iron in drinking water leads to neurodegenerative disorders and formation of ochre deposition that causes hydraulic clogging problem in drinking water network. Luis ${ }^{5}$ studied Salinity and alkaline $\mathrm{pH}$ in irrigation water effects on marigold plants. Here irrigation water having $\mathrm{pH}$ values 6.4 and 7.8 were supplied to plants and it was observed that plants that are grown with $\mathrm{pH} 6.4$ water have more flowers than that of $\mathrm{pH} 7.8$ water. R.S ubashree ${ }^{6}$ studied Investigation of coagulation activity of lemon peel and banana peel powder in water treatment. They prepared synthetic turbid water using Kaolin clay and created an initial turbidity of $38 \mathrm{NTU}$. It was reduced to $1.52 \mathrm{NTU}$ using banana peel powder and lemon peel powder. S. Anju and $\mathrm{K}$. MophinKani ${ }^{7}$ studied Exploring the use of orange peel and neem leaf powder as alternative coagulant in treatment of dairy waste water. Here initial turbidity was 260 NTU and it was reduced to 4 NTU and 8 NTU using neem leaf and orange-peel powder respectively.

\section{COAGULANTS USED IN THE PRESENT STUDY}

Two types of coagulants are considered in this present study as expressed earlier. Orange peel powder is the natural coagulant considered and Alum is the chemical coagulant considered. Alum (Aluminum Sulphate) is a nontoxic material commonly used in water treatment plants to clarify drinking water. In lakes alum is used to reduce the amount of the nutrient phosphorus in the water in order to limit the availability of this nutrient for algae production [6]. On contact with water, alum forms a fluffy aluminum hydroxide precipitate called floc. Aluminum hydroxide binds with phosphorus to form an aluminum phosphate compound. This compounds insoluble in water under most conditions so the phosphorus in it can no longer be used as food by algae organisms. As the floc slowly settles, some phosphorus is removed from the water. The floc also tends to collect suspended particles in the water and carries them down to the bottom, leaving the lake noticeably clearer[6]. When alum is mixed with water the following reactions takes place.

$$
\begin{gathered}
\text { 1. } \mathrm{Al}_{2}\left(\mathrm{SO}_{4}\right)_{3}+18 \mathrm{H}_{2} \mathrm{O}+3 \mathrm{Ca}\left(\mathrm{HCO}_{3}\right)_{2} 3 \mathrm{CaSO}_{4} \\
+2 \mathrm{Al}(\mathrm{OH})_{3}+6 \mathrm{CO}_{2}+18 \mathrm{H}_{2} \mathrm{O} \\
2.3 \mathrm{Ca}\left(\mathrm{HCO}_{3}\right)_{2} 3 \mathrm{CaCO}_{3}+3 \mathrm{CO}_{2}+3 \mathrm{H}_{2} \mathrm{O} 3 \\
\text { 3. } \mathrm{CaCO}_{3} 3 \mathrm{CaO}+3 \mathrm{CO}_{2} .
\end{gathered}
$$

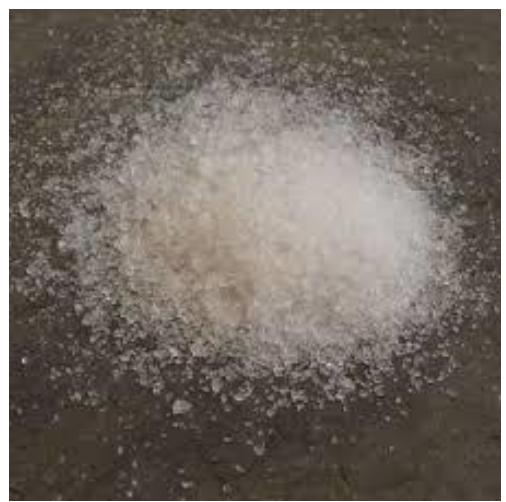

Fig:1 Alum $\left(\mathrm{Al}_{2}(\mathrm{SO} 4)_{3} .18 \mathrm{H}_{2} \mathrm{O}\right)$

Orange Peel Powder: Orange peel is largely composed of cellulose pectin, hemi-cellulose, lignin and other low molecular weight compounds including limestone. It can be used as an efficient and cost-effective bio-adsorbent for removing dyes metals and organic pollutants from wastewater [5]. In addition, orange peel is alternative as an adsorbent for its abundance in nature, non-toxicity and bio-degradability. This study was performed to utilize the orange peel as a low-cost natural adsorbent with respect to various parameters such as different doses and $\mathrm{pH}$.

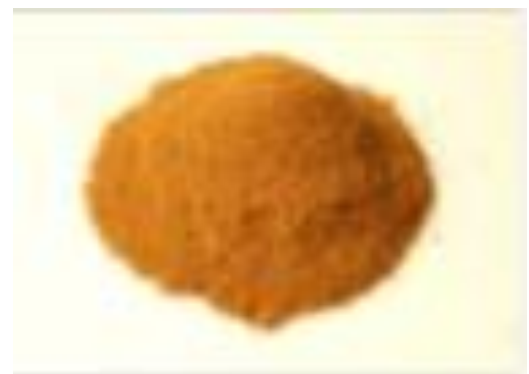

Fig:2 Orange Peel Powder

\section{METHODOLOGY OF THE PRESENT STUDY}

Water sampling is done from Kundu River and tests were conducted to know the quality of water soon after its collection. $\mathrm{pH}$ of water is determined using $\mathrm{pH}$ meter of Eleco make. Nepehlometric turbidity meter is adopted to estimate the turbidity of collected river water. Alkalinity and acidity of river water were found using titration method. To determine the optimum dosage of coagulant required to bring down the turbidity of water, Jar test apparatus is adopted which has a facility f mechanical stirring. In this study, by doing coagulation test for different dosages, optimum dosage of coagulants for both natural and chemical type was determined. And at this stage, $\mathrm{pH}$, turbidity, alkalinity and acidity were also determined. In the later stage, maintaining the $\mathrm{pH}$ value of $6.0,7.0,8.5$, optimum dosages of chemical and natural coagulants were determined for each series of $\mathrm{pH}$ value. 


\section{TESTS ON RIVER WATER}

Water sampling is done in Kundu river water and preliminary tests were conducted to know properties like turbidity, acidity and alkalinity. Below is the table which represents the preliminary test results done to know the Characteristics.

TABLE I: TEST RESULTS CONDUCTED ON RAW WATER SOON AFTER COLLECTION

\begin{tabular}{|c|c|c|}
\hline $\begin{array}{c}\text { Characteristics of } \\
\text { water }\end{array}$ & $\begin{array}{c}\text { Test } \\
\text { Results }\end{array}$ & $\begin{array}{c}\text { Allowable } \\
\text { Range as per IS }\end{array}$ \\
\hline Turbidity & $22.8 \mathrm{NTU}$ & $1-5 \mathrm{NTU}$ \\
\hline pH & 7.46 & $6.5-8.5$ \\
\hline Alkalinity & $96 \mathrm{mg} / \mathrm{l}$ & $200-600 \mathrm{mg} / 1$ \\
\hline Acidity & $8 \mathrm{mg} / \mathrm{l}$ & $<50 \mathrm{mg} / \mathrm{l}$ \\
\hline
\end{tabular}

As per Bureau of Indian Standards [7], the permissible limits of turbidity are $1-5$ NTU, but the river water has a very high turbidity which is showing 22.4 reading on Nephelometer scale. Other parameters like $\mathrm{pH}$, acidity and alkalinity are with in permissible limits.

\section{TABLE II. TESTS CONDUCTED ON THE RAW WATER SAMPLE}

\begin{tabular}{|r|c|c|}
\hline $\begin{array}{c}\text { S. } \\
\text { No }\end{array}$ & Experiments & Equipment \\
\hline 1 & $\mathrm{pH}$ & $\mathrm{pH}$ meter \\
\hline 2 & Turbidity & Nepehlometric Meter \\
\hline 3 & Coagulation & $\begin{array}{c}\text { Flocculator with flash } \\
\text { mixers }\end{array}$ \\
\hline 4 & Alkalinity & Titration method \\
\hline 5 & Acidity & Titration method \\
\hline
\end{tabular}

Initially the $\mathrm{pH}$, Turbidity, Alkalinity and Acidity of raw water was tested and then the $\mathrm{pH}$ values where changed to Acidic, Neutral and Alkalinity state i.e. maintaining the $\mathrm{pH}$ values of raw water as 6 (Acidic nature), 7 (Neutral) and 8 (Alkalinity nature). $\mathbf{p H}-\mathbf{6}$ ThepH of water is changed to 6 by adding drop by drop HCL. For each addition of drop of HCL the sample is tested for $\mathrm{pH}$ in $\mathrm{pH}$ meter

TABLE III: TEST ON RAW WATER AT PH 6

\begin{tabular}{|c|l|l|}
\hline S.No & TEST & RAWWATER \\
\hline 1 & $\mathrm{pH}$ & 6 \\
\hline 2 & Turbidity & $22.8 \mathrm{NTU}$ \\
\hline 3 & Alkalinity & $80 \mathrm{mg} / \mathrm{l}$ \\
\hline 4 & Acidity & $20 \mathrm{mg} / \mathrm{l}$ \\
\hline
\end{tabular}

pH - 7. The $\mathrm{pH}$ of water is changed to 7 by adding drop by drop HCL. For each addition of drop of HCL the sample is tested for $\mathrm{pH}$ in $\mathrm{pH}$ meter.
TABLE IV: TEST ON RAW WATER AT PH 7

\begin{tabular}{|l|l|l|}
\hline S.No & TEST & RAWWATER \\
\hline 1 & $\mathrm{pH}$ & 7 \\
\hline 2 & Turbidity & $22.8 \mathrm{NTU}$ \\
\hline 3 & Alkalinity & $90 \mathrm{mg} / \mathrm{l}$ \\
\hline 4 & Acidity & $14 \mathrm{mg} / \mathrm{l}$ \\
\hline
\end{tabular}

pH -8.5 The $\mathrm{pH}$ of water is changed to 8.5 by adding drop by drop $\mathrm{NaOH}$. For each addition of drop of $\mathrm{NaOH}$ the sample is tested for $\mathrm{pH}$ in $\mathrm{pH}$ meter.

TABLE V: TEST ON RAW WATER AT PH 8.5

\begin{tabular}{|r|c|c|}
\hline \multicolumn{1}{|c|}{ S. } & $\begin{array}{c}\text { Characteris } \\
\text { tics of water }\end{array}$ & $\begin{array}{c}\text { Test } \\
\text { Results }\end{array}$ \\
\hline 1 & pH & 8.5 \\
\hline 2 & Turbidity & $22.8 \mathrm{NTU}$ \\
\hline 3 & Alkalinity & $102 \mathrm{mg} / \mathrm{l}$ \\
\hline 4 & Acidity & $4 \mathrm{mg} / \mathrm{l}$ \\
\hline
\end{tabular}

TABLE VI: COAGULATION OF RIVER WATER WITH ALUM

\begin{tabular}{|c|c|c|c|c|c|c|}
\hline 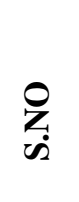 & 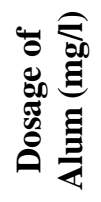 & Ta & 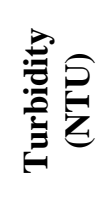 & 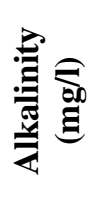 & 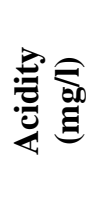 & 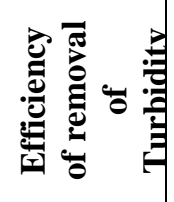 \\
\hline \multicolumn{7}{|c|}{ Raw Water } \\
\hline 1 & 0 & 7.46 & 22.8 & 96 & 8 & \\
\hline 2 & 5 & 7.47 & 18.9 & 94.3 & 8.5 & \\
\hline 3 & 10 & 7.45 & 16.7 & 92.7 & 8.9 & \\
\hline 4 & 15 & 7.45 & 11.3 & 90.1 & 9.3 & \\
\hline 5 & 20 & 7.46 & 7.5 & 89.8 & 9.4 & \\
\hline 6 & 25 & 7.47 & 5.2 & 87.4 & 9.7 & \\
\hline 7 & 30 & 7.46 & 3.3 & 86.5 & 9.9 & \\
\hline 8 & 35 & 7.47 & 1.7 & 86.2 & 10 & \\
\hline 9 & 40 & 7.47 & 0.5 & 85.9 & 10.2 & \\
\hline 10 & 45 & 7.43 & 1.2 & 84.9 & 10.2 & \\
\hline 11 & 50 & 7.44 & 1.5 & 83.2 & 10.3 & \\
\hline \multicolumn{7}{|c|}{ pH - 6} \\
\hline 1 & 0 & 6.03 & 22.8 & 80 & 20 & \\
\hline 2 & 5 & 6.03 & 20.6 & 79.7 & 20 & \\
\hline 3 & 10 & 6.02 & 19.4 & 79.5 & 20.5 & \\
\hline 4 & 15 & 6.01 & 5 & 78.7 & 21.2 & \\
\hline 5 & 20 & 6.05 & 3.2 & 78.5 & 21.9 & \\
\hline 6 & 25 & 6.03 & 0.3 & 78.3 & & 98.68 \\
\hline
\end{tabular}


Experimental Methodology of Optimum Coagulation Activity on River Water using Chemical and Natural Coagulants for Different pH Ranges

\begin{tabular}{|c|c|c|c|c|c|c|}
\hline 7 & 30 & 6.02 & 2.8 & 77 & 22.9 & \\
\hline \multicolumn{7}{|c|}{$\mathbf{p H ~ - 7}$} \\
\hline 1 & 0 & 7.03 & 22.8 & 90 & 14 & \\
\hline 2 & 5 & 7.03 & 20.6 & 89.6 & 14.6 & \\
\hline 3 & 10 & 7.01 & 17.4 & 89.2 & 14.9 & \\
\hline 4 & 15 & 7.02 & 11.2 & 87.1 & 15.1 & \\
\hline 5 & 20 & 7.02 & 5 & 85.6 & 15.8 & \\
\hline 6 & 25 & 7.05 & 2.2 & 84.8 & 15.8 & \\
\hline 7 & 30 & 7.05 & 1.4 & 83.3 & 15.9 & \\
\hline 8 & 35 & 7.03 & 0.5 & 81.2 & 16.7 & $\mathbf{9 7 . 8}$ \\
\hline 9 & 40 & 7.03 & 1.8 & 80.9 & 17.2 & \\
\hline \multicolumn{7}{|c|}{$\mathbf{p H}-\mathbf{8 . 5}$} \\
\hline 1 & 0 & 8.51 & 22.8 & 102 & 4 & \\
\hline 2 & 5 & 8.51 & 19.6 & 101.8 & 3.8 & \\
\hline 3 & 10 & 8.5 & 17.1 & 101.6 & 4.2 & \\
\hline 4 & 15 & 8.5 & 12.4 & 101.4 & 4.7 & \\
\hline 5 & 20 & 8.51 & 9.2 & 101.4 & 5.9 & \\
\hline 6 & 25 & 8.51 & 8.7 & 101.1 & 6.3 & \\
\hline 7 & 30 & 8.5 & 4.3 & 101.1 & 6.3 & \\
\hline 8 & 35 & 8.5 & 3.2 & 101.1 & 6.6 & \\
\hline 9 & 40 & 8.52 & 2.4 & 100.2 & 6.8 & \\
\hline 10 & 45 & 8.52 & 1.7 & 99.8 & 7 & \\
\hline 11 & 50 & 8.51 & 1.1 & 99.8 & 7.4 & \\
\hline 12 & 55 & 8.52 & 0.6 & 99.6 & 7.6 & 97.36 \\
\hline 13 & 60 & 8.53 & 1.9 & 99.3 & 8.4 & \\
\hline
\end{tabular}

\section{DOSAGE OF ALUM V/S ALKALINITY AT DIFFERENT pH VALUES OF RIVER WATER}

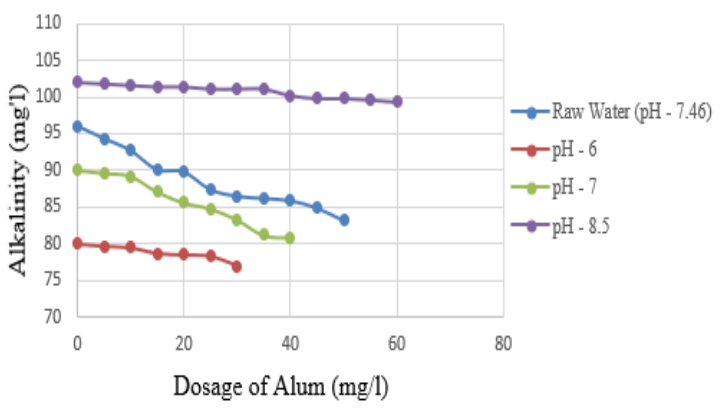

DOSAGE OF ALUM V/S ACIDITY AT DIFFERENT PH VALUES OF RIVER WATER

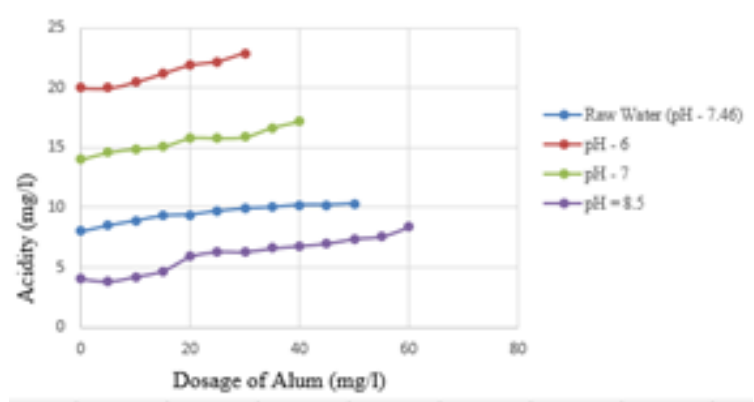

TABLE VII: COAGULATION OF RIVER WATER WITH ORANGE PEEL POWDER

The dosage of alum required to reduce turbidity of river water is less for $\mathrm{pH} 6$ and is high for $\mathrm{pH}$ 8.5. The graphs show that with increase in alkaline nature of water the optimum dosages required to obtain the residual turbidity are increased. The efficiency of removal of turbidity at $\mathrm{pH} 6$ is $98.68 \%, \mathrm{pH} 7$ is $97.8 \%, \mathrm{pH} 8.5$ is $97.36 \%$ of initial turbidities. The alkalinities and acidities obtained at optimum dosages are within the desirable standard limits as per BIS. The alkalinity values are decreased and acidity values are increased with increase in dosage of alum. The alkalinity is

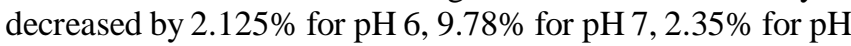
8.5 of initial alkalinity. The acidity values are increased by $11 \%$ for $\mathrm{pH} 6,19.28 \%$ for $\mathrm{pH} 7,90 \%$ for $\mathrm{pH} 8.5$ of initial acidity.

DOSAGE OF ALUM V/S TURBIDITY AT DIFFERENT pH VALUES OF
RIVER WATER

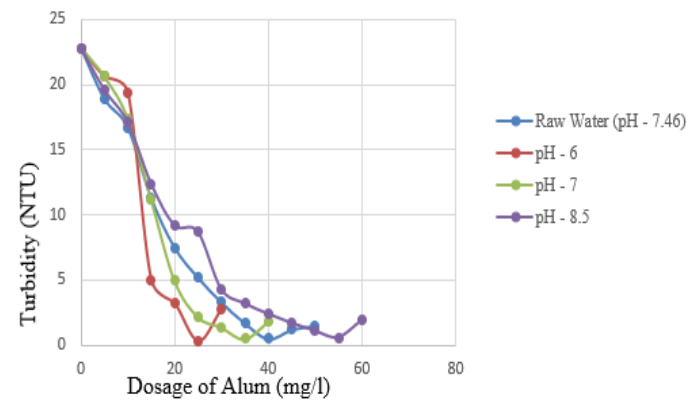




\begin{tabular}{|c|c|c|c|c|c|c|}
\hline 7 & 103 & $\begin{array}{c}6.0 \\
4\end{array}$ & 0.3 & 73.9 & 24.7 & 98.68 \\
\hline 8 & 120 & $\begin{array}{c}6.0 \\
2 \\
\end{array}$ & 3.1 & 72.9 & 25.9 & \\
\hline \multicolumn{7}{|c|}{ pH -7} \\
\hline 1 & 0 & $\begin{array}{c}7.0 \\
3\end{array}$ & 22.8 & 90 & 14 & \\
\hline 2 & 20 & $\begin{array}{c}7.0 \\
2\end{array}$ & 20.5 & 89.4 & 15.5 & \\
\hline 3 & 40 & $\begin{array}{c}7.0 \\
2\end{array}$ & 17.6 & 88.4 & 16.4 & \\
\hline 4 & 60 & $\begin{array}{c}7.0 \\
5\end{array}$ & 14.7 & 88.6 & 16.9 & \\
\hline 5 & 80 & $\begin{array}{c}7.0 \\
4\end{array}$ & 10.9 & 86.3 & 17.8 & \\
\hline 6 & 120 & $\begin{array}{c}7.0 \\
4\end{array}$ & 1.1 & 85.2 & 18.6 & \\
\hline 7 & 129 & $\begin{array}{c}7.0 \\
2\end{array}$ & 0.9 & 84.9 & 19.7 & 96.05 \\
\hline 8 & 140 & $\begin{array}{c}7.0 \\
1 \\
\end{array}$ & 2.6 & 83.9 & 20.9 & \\
\hline \multicolumn{7}{|c|}{$\mathrm{pH}-8.5$} \\
\hline 1 & 0 & $\begin{array}{c}8.5 \\
2\end{array}$ & 22.8 & 102 & 4 & \\
\hline 2 & 20 & 8.5 & 22.4 & 100.4 & 5.5 & \\
\hline 3 & 60 & $\begin{array}{c}8.5 \\
3 \\
\end{array}$ & 15.6 & 99.7 & 6.6 & \\
\hline 4 & 80 & $\begin{array}{c}8.5 \\
2\end{array}$ & 12.1 & 98.6 & 7.5 & \\
\hline 5 & 100 & $\begin{array}{c}8.5 \\
2\end{array}$ & 10.9 & 96.3 & 8.2 & \\
\hline 6 & 120 & $\begin{array}{c}8.5 \\
3\end{array}$ & 8.9 & 95.9 & 9.7 & \\
\hline 7 & 140 & $\begin{array}{c}8.5 \\
3\end{array}$ & 6.9 & 95.1 & 10.1 & \\
\hline 8 & 160 & $\begin{array}{c}8.5 \\
5\end{array}$ & 5.3 & 94.9 & 10.9 & \\
\hline 9 & 180 & $\begin{array}{c}8.5 \\
2 \\
\end{array}$ & 2.1 & 94.1 & 11.2 & \\
\hline 10 & 200 & $\begin{array}{c}8.5 \\
2\end{array}$ & 1.6 & 93.7 & 11.5 & \\
\hline 11 & 205 & $\begin{array}{c}8.5 \\
6\end{array}$ & 0.3 & 92.5 & 11.9 & 98.68 \\
\hline 12 & 220 & $\begin{array}{c}8.5 \\
1 \\
\end{array}$ & 3.5 & 91.6 & 12.5 & \\
\hline
\end{tabular}

\section{DOSAGE OF ORANGE PEEL POWDER V/S ALKALINITY AT DIFFERENT $\mathrm{pH}$ VALUES OF RIVER WATER}

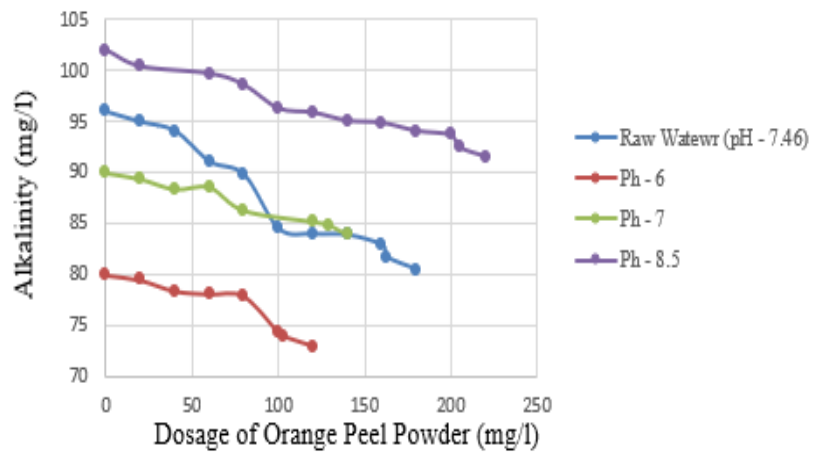

DOSAGE OF ORANGE PEEL POWDER V/S ACIDITY AT DIFFERENT $\mathrm{pH}$ VALUES OF RIVER WATER

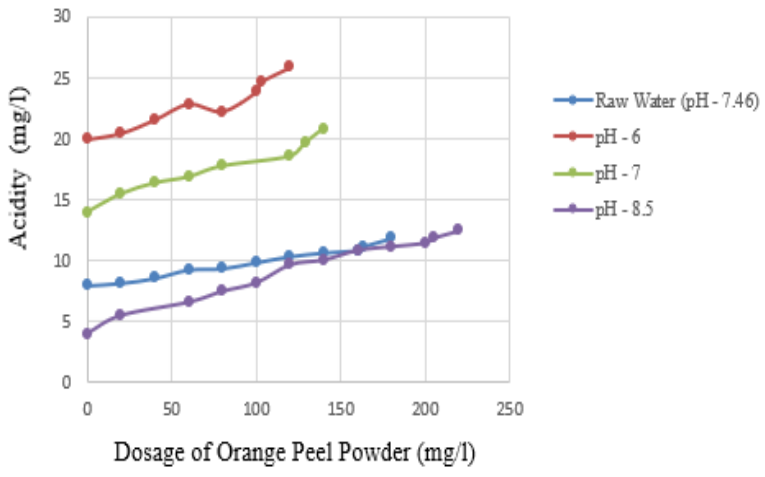

The turbidity at $\mathrm{pH} 6$ is $98.68 \%, \mathrm{pH} 7$ is $96.05 \%, \mathrm{pH} 8.5$ is $98.68 \%$ of initial turbidities. The alkalinities and acidities obtained at optimum dosages are within the desirable standard limits as per BIS. The alkalinity values are decreased and acidity values are increased with increase in dosage of orange peel powder. The alkalinity is decreased by

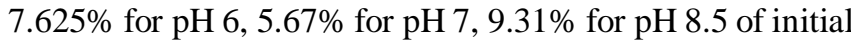
alkalinity. The acidity values are increased by $23.5 \%$ for $\mathrm{pH}$ $6,40.71 \%$ for $\mathrm{pH} 7,197.5 \%$ for $\mathrm{pH} 8.5$ of initial acidity.

\section{CONSOLIDATED RESULTS}

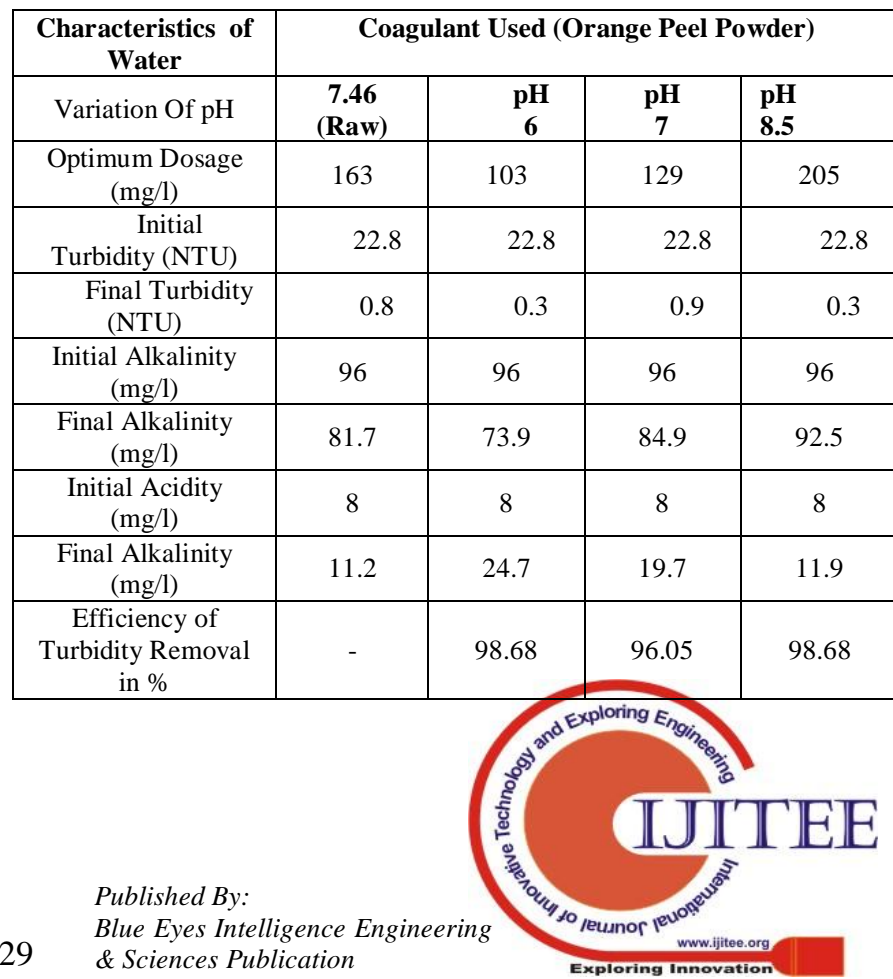




\begin{tabular}{|c|c|c|c|c|}
\hline Characteristics of & & agulant & ed (Alun & \\
\hline Variation Of pH & $\begin{array}{c}7.46 \\
\text { (Raw) }\end{array}$ & $\begin{array}{c}\mathrm{pH} \\
6 \\
\end{array}$ & pH 7 & $\begin{array}{l}\mathrm{pH} \\
8.5\end{array}$ \\
\hline $\begin{array}{c}\text { Optimum Dosage } \\
(\mathrm{mg} / \mathrm{l})\end{array}$ & - & 26 & 33 & 55 \\
\hline $\begin{array}{c}\text { Initial } \\
\text { Turbidity (NTU) } \\
\end{array}$ & $8^{22 .}$ & 22.8 & $8^{22 .}$ & 22.8 \\
\hline $\begin{array}{l}\text { Final Turbidity } \\
\text { (NTU) }\end{array}$ & - & 0.3 & 0.5 & 0.6 \\
\hline $\begin{array}{l}\text { Initial Alkalinity } \\
(\mathrm{mg} / \mathrm{l})\end{array}$ & 96 & 96 & 96 & 96 \\
\hline $\begin{array}{c}\text { Final Alkalinity } \\
(\mathrm{mg} / \mathrm{l})\end{array}$ & - & 78.3 & 81.2 & 99.6 \\
\hline $\begin{array}{c}\text { Initial Acidity } \\
(\mathrm{mg} / \mathrm{l})\end{array}$ & 8 & 8 & 8 & 8 \\
\hline Final Acidity $(\mathrm{mg} / \mathrm{l})$ & - & 22.2 & 16.7 & 7.6 \\
\hline $\begin{array}{c}\text { Efficiency of } \\
\text { Turbidity Removal } \\
\text { in } \%\end{array}$ & - & 98.68 & 97.8 & 97.36 \\
\hline
\end{tabular}

\section{CONCLUSION}

The access to safe and clean drinking water is a major concern throughout the world. Surface water has become the most common source for raw water, when large quantities of ground water often are inaccessible and as surface water requires more treatment, simple, cheap and efficient process methods are necessary. Turbidity removal is essential for treatment of surface water and is often carried out with coagulation using metal salts as aluminum sulphate. The soluble particles in the water attaches to the active agents, that binds them together creating large flocs in the water. The natural coagulant used to show good coagulating properties. Using natural coagulants does not lead to leaving of residuals like iron and aluminum to water which affect the human health. Also, the main advantage of using a natural coagulant is reducing sludge volume and thus reducing the amount of material to manage (i.e. de-water) or dispose of. Also, the sludge settled after the treatment can be used as bio fertilizers in added advantages of this method in rural areas.

\section{FUTURE SCOPE}

When the water samples are treated with natural coagulants, taste and odor may tend to change. They also impart color to the samples. These should be analyzed and steps are to be taken to reduce to required levels as per standard limits before supplying to drinking and irrigation purpose.

\section{REFERENCES}

1. Wafai El-Hosseni Ahmed and Hanaa M. Sherif, "Effect of irrigation water $\mathrm{PH}$ on some soil properties and growth of some pear rootstocks grow on sand and calcareous soils" International Journal of Plant \& Soil Science, 4(5): 475-493, 2015; Article no.IJPSS.2015.047, ISSN: 2320-7035.

2. Akbar Baghvand, Ali Daryabeigi Zand, Nasser Mehrdadi and Abdolreza Karbassi, "Optimizing Coagulation Process for Low to High Turbidity Waters Using Aluminum and Iron Salts" American Journal of Environmental Sciences 6 (5): 442-448, 2010 ISSN 1553-345X.

3. BaiChuan Cao,BaoYu Gao, ChunHua Xu, Ying Fu, Xin Liu, "Effects of $\mathrm{pH}$ on coagulation behavior and floc properties in Yellow River water treatment using ferric based coagulants" Chinese Science Bulletin, May 2010, Volume 55, Issue 14, pp 1382-1387.

4. R.Subashree, N.Surya Praba, Dr.G.Anusha, "Investigation of Coagulation Activity of Lemon and Banana Peel Powder in Water Treatment" International Journal on Advanced Research in Science and Engineering, Volume No. 6, Issue No. 10, October 2017 pp 852-855.

5. Anju S and K.Mophin-Kani, "Exploring the Use of Orange Peel and Neem Leaf Powder as Alternative Coagulant in Treatment of Dairy Wastewater" International Journal of Scientific \& Engineering Research, Volume 7, Issue 4, April-2016, ISSN 2229-5518, pp 238-244.

6. Joseph Marie Sieliechi, Guifo Joseph Kayem, Ion Sandu, "Effect of Water Treatment Residuals (Aluminum and Iron Ions) on Human Health and Drinking Water Distribution Systems", International Journal of Conservation Science, Volume 1, Issue 3, July-September 2010, pp 175-182.

7. IS 10500:2012- Drinking Water Standards 